\title{
SEGMENTASI CITRA PARU-PARU MENGGUNAKAN METODE KONTUR AKTIF DENGAN VALIDASI ROC
}

\author{
Sintha Syaputri, Zulkarnain* \\ Jurusan Fisika FMIPA Universitas Riau \\ Fakultas Matematika dan Ilmu Pengetahuan Alam, \\ Universitas Riau Kampus Bina Widya \\ Jl. Prof. Muchtar Luthfi Pekanbaru, 28293, Indonesia \\ *E-mail korespondensi: zulkarnain22@gmail.com
}

\begin{abstract}
Segmentation is the process of separating parts of objects from the background by dividing images that have different object intensities with each other such as in imaging of body parts. Active contour segmentation was used for medical imaging that resistant to noise around objects. This study used 5 chest X-Ray images, specifically to the lungs with a grayscale format measuring $256 \times 256$ pixels, through the preprocessing process and filtering a Gaussian filter, each image was inputted to the $R 2015$ a version of the matlab GUI program. Then the segmentation had done by using the active contour method. In this method a curve in the form of a small circle was placed on the edge of object to be segmented. The curve will move according to the shape of the outer edge of the lung based on the values of active contour parameters such as Alpha, Beta, Gamma, Kappa, WEline, WEdge, WEterm and Iteration. Validation was done by using the ROC (Receiver Operating Characteristic) method and were obtained an average percentage with an accuracy value of $96.26 \%$, a specificity of $96.47 \%$ and a sensitivity of $76.54 \%$.
\end{abstract}

Keywords: Active contour segmentation, Lung, X-ray thorax, ROC

\begin{abstract}
ABSTRAK
Segmentasi merupakan proses pemisahan bagian objek terhadap latar dengan membagi citra yang memiliki intensitas objek yang berbeda antara satu dengan yang lain seperti pada pencitraan bagianbagian tubuh. Segmentasi kontur aktif digunakan untuk citra medis yang tahan terhadap noise di sekitar objek. Penelitian ini menggunakan 5 buah citra X-Ray thorax khususnya bagian paru-paru dengan format grayscale berukuran $256 \times 256$ pixel, melalui proses awal (preprocessing) dan filter menggunakan tapis Gaussian, masing-masing citra diinput ke program GUI matlab versi R2015a. Selanjutnya dilakukan segmentasi dengan menggunakan metode kontur aktif. Pada metode ini kurva berupa lingkaran kecil diletakkan di bagian objek yang akan disegmentasi. Kurva akan bergerak sesuai dengan bentuk tepi luar paru-paru berdasarkan nilai parameter-parameter kontur aktif berupa Alfa, Beta, Gamma, Kappa, WEline, WEdge, WEterm dan Iterasi. Validasi dilakukan dengan metode ROC (Receiver Operating Characteristic) didapatkan hasil persentase rata-rata dengan nilai akurasi $96.26 \%$, spesifitas $96,47 \%$ serta sensitifitas $76,54 \%$.
\end{abstract}

Kata Kunci: Segmentasi aktif kontur, Paru-paru, X-Ray thorax, ROC

Diterima 12-07-2019| Disetujui 30-09-2019| Dipublikasi 31-10-2019

\section{PENDAHULUAN}

Teknik pengolahan citra digital merupakan salah satu produk pengembangan dari teknologi komputasi [1]. Pengolahan data citra medis berbasis komputer mempermudah dokter mencermati suatu keabnormalan dengan cepat dan tepat, namun potensi ini belum banyak tergali baik untuk riset ataupun untuk keperluan rumah sakit di Indonesia [2]. Teknologi ini membantu tenaga medis untuk mendiagnosa yang lebih baik dan akurat 
berdasarkan irisan anatomi yang direpresentasikan pada citra.

Citra X-Ray thorax adalah citra yang menampilkan penampang organ tubuh bagian dalam manusia khususnya pada bagian rongga dada [3]. Thorax (rongga dada) adalah daerah tubuh yang terletak diantara leher dan abdomen [4]. Dokter ahli penyakit dalam menyatakan bahwa paru-paru merupakan organ dalam yang paling rawan mengalami kerusakan, hal ini disebabkan fungsi paru-paru yang bersentuhan secara langsung dengan lingkungan luar, karena paru-paru berfungsi mengambil udara dari luar tubuh (lingkungan). Pemeriksaan yang lebih teliti diperlukan dari setiap perubahan pada organ-organ yang ada di rongga dada, terutama paru-paru [5].

Citra yang diamati secara manual kurang efektif dalam menentukan suatu diagnosa, sehingga menyebabkan analisis secara visual untuk objek jaringan atau organ yang menjadi perhatian sulit dilakukan.

Salah satu pengolahan citra digital adalah segmentasi. Keunggulan metode ini adalah tahan terhadap noise yang berada di sekitar objek, sehingga bentuk objek yang hendak diamati pada citra medis tertentu akan mudah dianalisa [6]. Segmentasi membagi citra ke dalam daerah intensitasnya masing-masing sehingga bisa membedakan antara objek dan background-nya. Pembagian ini tergantung pada masalah yang akan diselesaikan. Segmentasi harus dihentikan apabila masingmasing objek telah terisolasi atau terlihat dengan jelas. Kontur aktif berupa kumpulan titik yang bergerak mendekati batasan dari suatu objek.

\section{TINJAUAN PUSTAKA}

Fungsi energi yang digambarkan kontur aktif terdiri dari beberapa komponen sebagai berikut [7].

$$
\begin{aligned}
& E_{\bar{A}}=\int_{\square}^{1}\left\{E_{\square}(v(s)]+E_{\square]} \quad(v(s)\}\right. \\
& \left.+E_{G}(v(s))\right\} \cdot d
\end{aligned}
$$

dimana $E_{A}$ merupakan fungsi energi dari active contour, $v(s)$ merupakan kumpulan dari x dan y koordinat dari kurva kontur aktif, $E_{i 1}$ merupakan energi internal kontur aktif, energi ini mempengaruhi pegerakan dari kurva kontur aktif, $E_{i}$ merupakan energi dari gambar digital yang menjadi input, dan $E_{c}$ high level information yang mempengaruhi pergerakan dari kurva kontur aktif [6].

ROC (Receiver Operating Characteristics) merupakan suatu pengukuran dalam uji diagnostik, dalam dunia medis pengukuran tersebut digunakan untuk evaluasi tes medis. Suatu aplikasi segmentasi harus memiliki akurasi yang cukup, untuk memenuhi persyaratan tersebut, peneliti menggunakan metode pengukuran ROC yaitu menghitung nilai akurasi, sensitifitas, dan spesifitas pada citra hasil segmentasi dengan membandingkan hasil segmentasi citra ujicoba pada citra asli [7].

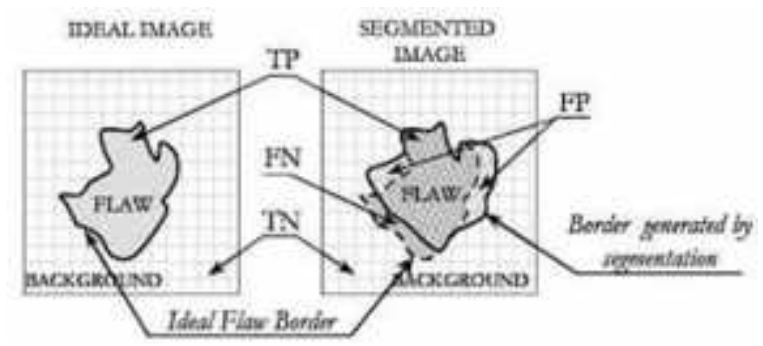

Gambar 1. Perbedaan antara citra paru-paru asli dengan citra hasil segmentasi [8]

Gambar 1 merupakan pembagian daerah TP, TN, FP, dan FN pada citra paru-paru asli dengan citra hasil segmentasi. Keempat nilai tersebut dihitung berdasarkan jumlah pixel yang dilingkupi dan dihitung akurasi, sensitifitas serta spesifitasnya.

$$
\begin{array}{ccc}
A & = & T+T \\
& & =\frac{T}{T+F} \\
S & & =\frac{T}{T+F}
\end{array}
$$

dimana TP adalah true positif (nilai kebenaran antara hasil gambar ujicoba dengan paru-paru), $\mathrm{TN}$ adalah true negatif (nilai kebenaran antara hasil gambar ujicoba dengan background), FP adalah false positif (nilai ketidaktepatan antara hasil gambar ujicoba dengan paru-paru), dan FN adalah false positif (nilai ketidaktepatan antara hasil gambar ujicoba dengan background) [9].

\section{METODE PENELITIAN}

Pengolahan data citra medis X-Ray thorax ini dengan menggunakan program MATLAB 
R2015a dengan sistem GUI. Penelitian ini dimulai input data citra. Hasil dari segmentasi dengan menggunakan metode kontur aktif dibandingkan dengan hasil segmentasi manual. Langkah-langkah penelitian dapat digambarkan dalam bentuk diagram alir program seperti yang terlihat pada gambar 2 .

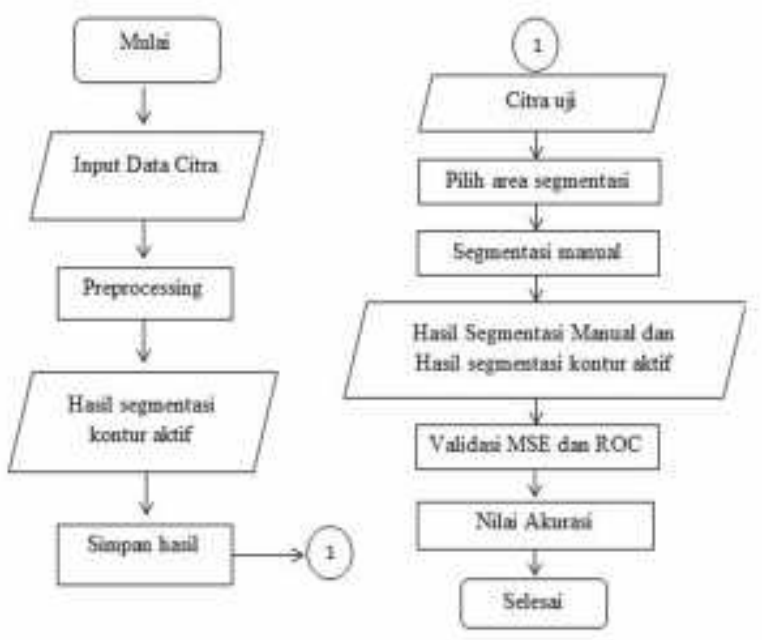

Gambar 2. Diagram alir program

Objek citra sebanyak 5 citra adalah file citra X-Ray thorax yang berformat JPG, berukuran 256 x 256 piksel. Gambar 3 adalah objek yang akan diteliti.

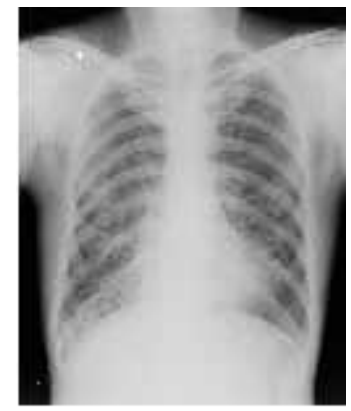

Gambar 3. Contoh data citra X-Ray thorax.

\section{Preprocessing (Tahapan Awal)}

Proses ini merupakan kumpulan dari proses yang digunakan untuk dapat menghasilkan segmentasi yang terbaik. Preprocessing yang digunakan adalah konversi dan perbaikan citra (Image Enhancement). Proses konversi citra dilakukan dari citra RGB menjadi citra grayscale (gambar yang memiliki tingkat warna keabuan). Proses kedua yaitu perbaikan citra, dalam hal ini menggunakan filter atau tapis gaussian untuk menghaluskan citra dan mengurangi noise atau derau pada citra. Proses di atas dapat memudahkan dalam hal segmentasi dengan menggunakan kontur aktif.

\section{Segmentasi Kontur Aktif}

Segmentasi dapat digunakan dalam mendeteksi pinggiran suatu objek. Langkah pertama yang dilakukan adalah melakukan inisialisasi kurva apabila citra tersebut telah melalui proses preprocessing. Kurva inisialisasi berbentuk lingkaran kecil dimana setiap lingkaran tersebut diletakkan di bagian objek yang akan disegmentasi khususnya pada bagian paru-paru.

Tahap ini selesai, selanjutnya memberikan nilai iterasi pada objek tersebut agar proses segmentasi bisa berjalan dan mendeteksi tepian dari gambar atau objek yang ingin disegmentasi. Hasil dari segmentasi tersebut kemudian menjadi citra biner karena dapat memudahkan proses perbandingan antara hasil segmentasi manual paru-paru dengan hasil segmentasi menggunakan kontur aktif.

\section{HASIL DAN PEMBAHASAN \\ Pengujian Citra Thorax Img0211}

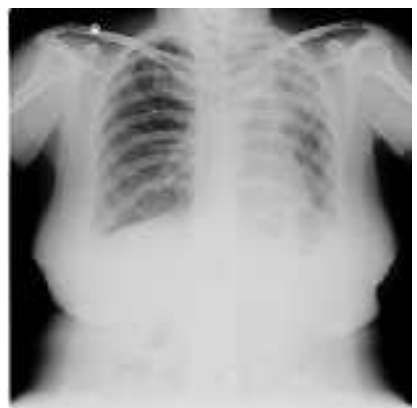

Gambar 4. Citra throax Img0211

Adapun penentuan posisi koordinat kontur aktif snake yang digunakan adalah sebagai berikut.

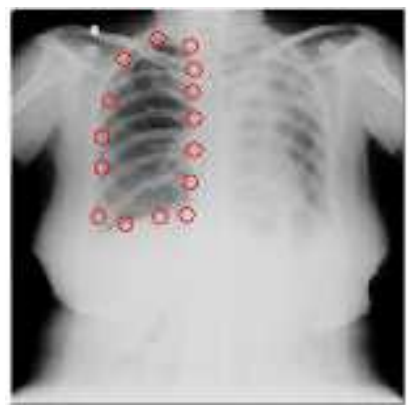

Gambar 5. Penentuan posisi snake citra thorax $\operatorname{Img} 0211$. 
Berdasarkan Gambar 5 terlihat bahwa penentuan posisi Snake dilakukan pada sisi kanan paru-paru. Selain itu, poisis koordinat kontur aktif Snake berada tepat di tepi-tepi objek. Berikut adalah hasil segmentasi citra thorax Img0211 yang dilakukan pada pengujian ini.

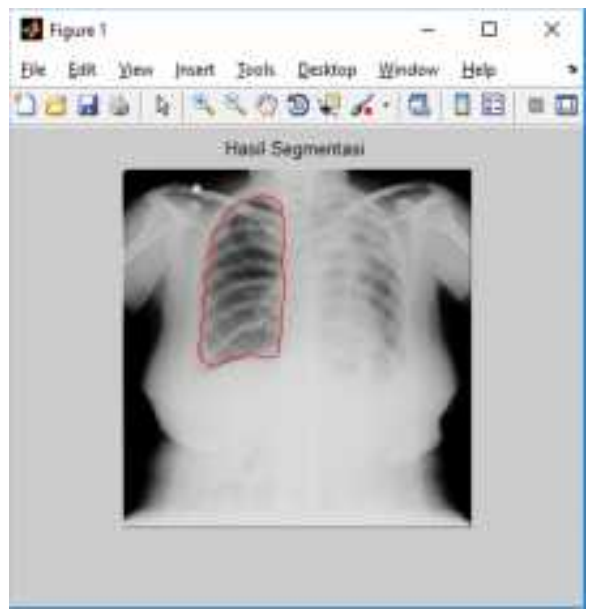

Gambar 6. Hasil segmentasi citra thorax Img0211.

Hasil segementasi dapat dilihat pada area paru-paru yang dibatasi garis warna merah. Berdasarkan Gambar 6 terlihat bahwa hasil segmentasi berada area paruparu, dimana metode kontur aktif berhasil mendeteksi tepi dari area paru-paru.

\section{Validasi ROC}

Tabel 1. Pengujian akurasi hasil segmentasi kontur aktif terhadap segmentasi manual dengan menggunakan metode ROC.

\begin{tabular}{llll}
\hline \multirow{2}{*}{ Citra } & \multicolumn{2}{l}{ ROC (\%) } & \\
\cline { 2 - 4 } & Akurasi & Sensitifitas & Spesifisitas \\
\hline Img0207 & 97.5098 & 78.8143 & 97.2664 \\
Img0208 & 93.4448 & 86.1401 & 90.5123 \\
Img0210 & 96.6141 & 68.743 & 96.3434 \\
Img0211 & 97.0764 & 70.4903 & 96.9219 \\
Img0212 & 96.6583 & 78.5613 & 96.3218 \\
\hline
\end{tabular}

Pengujian tingkat akurasi menggunakan metode ROC dilakukan terhadap hasil segmentasi kontur aktif dan hasil segmentasi manual dengan menggunakan data masukan sebanyak 5 citra. Hasil yang didapat merupakan hasil dari segmentasi paru-paru menggunakan metode kontur aktif, masingmasing citra dihitung nilai true positif, true negatif, false positif, dan false negatif sehingga didapatkan presentase akurasi, sensitifitas, dan spesifitas dalam bentuk presentase.

Berdasarkan Tabel 1. tingkat akurasi hasil segmentasi kontur aktif memiliki rata-rata sebesar 96.26068\%. Adapun tingkat sensitifitas dari hasil yang diperoleh memiliki rata-rata sebesar $76.5498 \%$. Sedangkat tingkat spesifisitas hasil segmentasi memiliki rata-rata sebesar 96.47316\%. Berdasarkan hasil tersebut dapat disimpulkan bahwa algoritma kontur aktif mampu melakukan segmentasi citra paru-paru dengan sangat baik.

Penelitian yang dilakukan oleh Haryadi [10] tentang segmentasi citra X-Ray paru-paru menggunakan Max-Tree dan geometri kontur aktif, didapatkan hasil segmentasi dengan nilai akurasi sebesar $96.17 \%$, nilai sensitifitas sebesar 93.36, dan nilai spesifisitas sebesar $97.78 \%$. Apabila dibandingkan terhadap hasil yang diperolah pada penelitian ini, maka dapat disimpulkan bahwa hasil yang diperoleh memiliki tingkat akurasi, tingkat sensitifitas, dan tingkat spesifisitas yang hampir sama dan hasilnya tidak jauh berbeda [10].

\section{KESIMPULAN}

Berdasarkan hasil penelitian yang diperoleh dari segmentasi Paru-paru pada citra X-Ray thorax menggunakan metode kontur aktif didapatkan beberapa kesimpulan sebagai berikut:

1. Program untuk segmentasi paru-paru pada citra X-Ray thorax menggunakan metode kontur aktif berhasil dilakukan dengan sistem GUI yang terdapat pada Matlab. Segmentasi menggunakan kontur aktif berhasil mendeteksi tepi-tepi objek pada citra paru-paru X-Ray thorax sehingga pengamatan terhadap citra paru-paru menjadi lebih jelas.

2. Penentuan koordinat posisi kontur aktif sangat mempengaruhi hasil segmentasi, dimana posisi koordinat kontur aktif tidak boleh terlalu jauh dari area yang ingin disegmentasi. Apabila posisi koordinat kontur aktif terlalu jauh dari area yang disegmentasi maka ketika proses dilakukan kontur aktif cendrung menjauh dari tepi objek.

3. Pengujian menggunakan metode ROC, didapatkan hasil yang menujukkan atas terlihat bahwa tingkat akurasi hasil segmentasi kontur aktif memiliki rata-rata yaitu $96.26 \%$. Adapun tingkat spesifisitas 
hasil segmentasi memiliki rata-rata sebesar $96.47 \%$. Sedangkan tingkat sensitifitas dari hasil yang diperoleh memiliki ratarata sebesar $76.54 \%$.

\section{REFERENSI}

1. Efford, N. (2000). Digital Image Processing: a Practical Introducing Using Java. USA: Pearson Education Limited.

2. Alfiansyah. A.Ng. 2009. Deformable Model for Serial Ultrasound Images Segmentation: Aplication to Computer Assisted Hip Athropasty. Singapore:International Conference on Bio Medical Engineering.

3. Supriyanto. Segmentasi Citra Secara Semiotomatis Untuk Visualisasi Volumetrik Citra CT-Scan Pelvis Makara. Teknologi vol. 13. no. 2. November 2009. pp.59-66.

4. Hartono, Wahyu. 2017. Segmentasi Paruparu pada Citra X-Ray Thorax Menggunakan K-Means. Skripsi. Universitas Islam Negeri Maulana Malik Ibrahim Malang.
5. Evelyn CP. 2009. Anatomi dan Fisiologi untuk Paramedis. Jakarta: PT Gramedia.

6. Proklamasi, Bara. 2013. Segmentasi Tulang Selangka pada Citra X-Ray Thorax dengan Menggunakan Metode Active Contour. Skripsi. Universitas Islam Negeri Maulana Malik Ibrahim Malang.

7. Hariyadi, Mokhamad Amin. 2009. Segmentasi Paru-paru Menggunakan Level Sets. Electrical Engineering Department.

8. Hayati, Ratri Nur Kumala. 2013. Segmentasi Paru-paru pada Citra Digital Hasil X-Ray Thorax Menggunakan Metode Level Set untuk Menghitung Diameter Maksimal Paru-paru. Skripsi. Universitas Islam Negeri Maulana Malik Ibrahim.

9. Mardiyah, Ainatul dan agus Harjoko. 2011. Metode Segmentasi Paru-paru dan Jantung pada Citra X-Ray Thorax. IJEIS (Indonesian Journal of Electronics and Instrumentation System).

10.Hariyadi, Mokhamad Amin dan Eviv Lailyana. 2011. Filtering dan Geometri Kontur Aktif untuk Menentukan Segmentasi Paru-paru pada Citra X-Ray Thorax. Berk Penel. 4E: 5-9. 